\title{
El nacionalismo argentino en los años de plomo: la revista Cabildo y el proceso de reorganización nacional (1976-1983)
}

\author{
Jorge Saborido
}

Universidad de Buenos Aires-

Universidad Nacional de La Pampa

El trabajo propone una revisión del pensamiento y el accionar del nacionalismo católico en la República Argentina durante la última dictadura militar, el autodenominado Proceso de Reorganización Nacional, a través de su principal órgano de prensa, la revista Cabildo. En él se analizan las circunstancias que llevaron inicialmente a un apoyo condicionado a la gestión de las Fuerzas Armadas, que se fue transformando en una crítica cada vez más dura, en tanto los militares en el poder no se mostraron dispuestos a poner en marcha la "revolución nacional" que se impulsaba desde la revista. Asimismo, se muestra cómo la ocupación de las islas Malvinas —una de las principales reivindicaciones de los nacionalistas - dio lugar a un corto período de acercamiento, que concluyó con la derrota en la guerra del Atlántico Sur.

PALABRAS CLAVE: nacionalismo católico, dictadura militar, antiliberalismo, antimarxismo, revolución nacional.

The paper proposes a revision of the discourse and practice of the National Catholicism in the Argentine Republic during the last military dictatorship, the self called "Proceso de Reorganización Nacional", through its print means, the Cabildo magazine. This paper analyses the trajectory of the magazine, since its initial support to the military forces -under the condition for the military forces to set in motion the "national revolution"to the increasingly hard criticism as far as the militaries in the government were not willing to carry out the revolution promoted in the magazine. In addition, the paper shows how the military occupation of the Falkland Islands - one of the main nationalistic claims-facilitated a short period of closer relation between the magazine and the military forces, something that concluded with the Argentine defeat in the South Atlantic War.

KeYwords: National Catholicism, Military Dictatorship, Antiliberalism, Antimarxism, National Revolution.

\section{Introducción}

El nacionalismo católico ha sido objeto de estudios de significación durante los últimos años en España, en la medida en que constituyó una de las principales fuentes de ideas del bando nacional en la guerra civil de 
1936-1939 y del régimen que se instauró después de ella . ${ }^{1}$ A partir de esas aportaciones ha quedado establecido con claridad su origen y sus componentes ideológicos, que se vinculan con un proceso más amplio, el de las corrientes de pensamiento surgidas en Europa como reacción frente a las transformaciones económicas, sociales, políticas y culturales que se verificaron sobre todo a partir del siglo XVIII, ${ }^{2}$ y que a partir de fines del siglo siguiente y principios del XX adquirieron renovado vigor como consecuencia, entre otras circunstancias, del intento de la más alta jerarquía eclesiástica de enfrentar los desafíos impuestos por la expansión del capitalismo liberal y el desarrollo de las corrientes socialistas.

En la Argentina, por su parte, el estudio del nacionalismo católico y de sus manifestaciones políticas concretas ha quedado subsumido dentro de los estudios sobre el nacionalismo y, como éstos, se han centrado en el momento de su surgimiento y en el desarrollo alcanzado durante la década del 30, hasta el ascenso al poder del peronismo. ${ }^{3}$ El período posterior a 1945 ha generado una atención menor, apareciendo el tema en obras generales sobre el nacionalismo, ${ }^{4} \mathrm{o}$ en estudios que rozan el tema parcialmente. ${ }^{5}$

En el trabajo que aquí se presenta nos proponemos abordar una cuestión puntual —el accionar político concreto del nacionalismo católico-, en un momento histórico acotado - la dictadura militar instalada en el poder en la Argentina entre 1976 y 1983-, a través de una fuente que consideramos de máxima relevancia: la revista Cabildo.

1 Podemos citar: Morodo, Raúl: Orígenes ideológicos del franquismo: Acción Española, Alianza, Madrid, 1985; Botti, Alfonso: Cielo y Dinero. El nacionalcatolicismo en España (1881-1975), Alianza, Madrid, 1992; González Cuevas, Pedro Carlos: Acción Española. Teología política y nacionalismo autoritario en España, Tecnos, Madrid, 1998.

2 El libro más conocido sobre el tema es: Herrero, Javier: Los orígenes del pensamiento reaccionario español, Alianza, Madrid, 1987 (Primera edición de 1973).

3 Buchrucker, Cristian: Nacionalismo y Peronismo. La Argentina en la crisis ideológica mundial (1927-1955), Sudamericana, Buenos Aires, 1987; Zanatta, Loris: Del Estado Liberal a la Nación Católica, Universidad Nacional de Quilmes, Buenos Aires,1996; Zanatta, Loris: Perón y la Nación Católica, Sudamericana, Buenos Aires, 1999; Devoto, Fernando: Nacionalismo, fascismo y tradicionalismo en la Argentina, Siglo XXI, Buenos Aires, 2002. Una excepción a lo que se está afirmando es el trabajo de Mallimacci, Fortunato: El Catolicismo integral en la Argentina (1930-1946), Biblos/Fundación Simón Rodriguez, Buenos Aires, 1988.

4 Zuleta Álvarez, Enrique: El nacionalismo argentino, Ediciones La Bastilla, Buenos Aires, 1975; Rock, David: La Argentina autoritaria. Los nacionalistas, su historia y su influencia en la vida pública, Ariel, Buenos Aires, 1993.

5 McGee Deutsch, Sandra y otros: La derecha argentina. Nacionalistas, neoliberales, militares y clericales, Javier Vergara, Buenos Aires, 2001; Zanatta, Loris: Religión, nación y derechos humanos. El caso argentino en perspectiva histórica, Revista de Ciencias Sociales, N. ${ }^{\circ}$-8, Universidad de Quilmes, 1998. 
Consideramos que el tema escogido y su tratamiento puede ayudar a resolver algunas de las claves de la importancia que tuvo una corriente de pensamiento que, si bien careció de presencia en el conjunto de la sociedad, ejerció una fuerte influencia sobre determinados sectores de poder - fundamentalmente los militares- en momentos históricos cercanos.

Puede sostenerse, en principio, que la instauración del Proceso de Reorganización Nacional, con su decidida vocación de reconstruir la sociedad argentina sobre nuevas bases, "dando vuelta la página" en todos los terrenos al tumultuoso pasado reciente, constituía un momento propicio para que el nacionalismo católico se transformara en el eje ideológico de la Argentina que los hombres de las Fuerzas Armadas intentaban edificar. Para que esta posibilidad tuviera ocasión de concretarse, existía un pasado de vinculación entre sectores de la Iglesia y del Ejército que sostenían estas posiciones, el que se remontaba, como bien lo han mostrado los trabajos de Zanatta, a fines de la década de 1920.

Sin embargo, las expectativas se frustraron. Justamente, la historia de este fracaso es la que vamos a intentar transitar; esto es, el período de más de siete años que se inicia con la elocuente apelación "Por la Nación contra el Caos", título de tapa del primer número de Cabildo publicado en agosto de 1976 y subtítulo general de la revista de allí en adelante, y concluye con la foto de Jorge Rafael Videla acompañada del epígrafe "Este gran culpable no debe quedar impune", que fue la portada del número de diciembre de 1983, momento en que Raúl Alfonsín asumía como presidente de la Nación.

La hipótesis que orienta la investigación es que el ideario cerrado que constituye el núcleo del pensamiento nacionalista católico — que se resumirá en el apartado siguiente - era inaplicable incluso para quienes, como la mayor parte de los militares del Proceso, estaban dispuestos a acabar de cualquier manera con el "caos y desgobierno" que había caracterizado la vida política argentina en las últimas décadas. Se sostiene, asimismo, que el discurso nacionalista, capaz de ganar adeptos en sectores significativos de las Fuerzas Armadas, predispuestos favorablemente porque constituía un elemento importante en el proceso de su formación como oficiales, carecía de todo realismo para ir más allá de brindar argumentos para la destrucción de las instituciones democráticas y la legitimación del terrorismo de Estado; su proyecto de "Nación Católica" era inviable para quienes no tenían muy claro qué era lo que querían hacer en muchos terrenos, pero sin duda estaban mayoritariamente decididos a no embarcarse en aventuras 
cuyo sustento ideológico y propuestas estaban a una distancia sideral de cualquier rumbo posible para el futuro argentino.

\section{Características de la publicación}

Desde su aparición en los turbulentos años 70, la revista Cabildo se constituyó en la expresión más emblemática del nacionalismo católico argentino. El primer número salió a la venta el 17 de mayo de 1973, ocho días antes de la asunción del Dr. Héctor J. Cámpora como presidente de la República Argentina, tras producirse el amplio triunfo del Frente Justicialista de Liberación en las elecciones del 11 de marzo de ese año.

El tono antidemocrático de sus cuestionamientos, que se centraban en la demanda continua a los militares para que tomaran el poder, llevó a que luego de la muerte del general Juan Domingo Perón, la revista fuera clausurada tres veces por el gobierno de Isabel Perón: primero en febrero del ' 75 (tras haber publicado 22 números); luego en mayo de ese mismo año (había reaparecido con el nombre de El Fortín), y finalmente en febrero del año siguiente, después de que en junio del ' 75 su prédica continuara en las páginas de Restauración.

Producido el golpe militar de 1976, Cabildo reinició su actividad normal el 6 de agosto de ese año especificando que se trataba de una "segunda época”, razón por la cual arrancó otra vez desde el número 1.

Durante el período del Proceso de Reorganización Nacional, Cabildo fue una publicación mensual, periodicidad que se mantuvo de manera medianamente regular (en varias ocasiones un número abarcaba dos meses). Cabe citar que en julio de 1977 una disposición del Poder Ejecutivo ordenó el secuestro del N. ${ }^{\circ} 8$, correspondiente al mes de junio y prohibió la edición del número correspondiente al mes siguiente.

A lo largo de esos años se mantuvieron en sus puestos tanto el director, Ricardo Curutchet, como el secretario de redacción, Juan Carlos Monedero, y se produjeron algunas modificaciones en el plantel de colaboradores, que incluía aportes tan significativos como el del líder de la hispánica Fuerza Nueva, Blas Piñar, el general Adel Edgardo Vilas, responsable del operativo antiguerrillero en la provincia de Tucumán, o el de intelectuales de larga militancia en el nacionalismo como Julio Irazusta, Federico Ibarguren o el cuyano Rubén Calderón Bouchet. En la época democrática, también participó como colaborador el general Ramón J. Camps, jefe de 
policía de la provincia de Buenos Aires, personaje sobre el que recayeron duras acusaciones respecto de la violación de derechos humanos. Las rotaciones en el staff no implicaron cambios relevantes en los planteamientos de la publicación; si bien se indicaba que "los artículos firmados no expresaban necesariamente la opinión de los integrantes de la revista", la línea era "bajada" por la dirección y los artículos tenían en todo momento una coherencia destacable. ${ }^{6} \mathrm{Si}$ bien existieron polémicas con otros grupos cercanos al nacionalismo — como la agrupación "Tradición, Familia y Propiedad"- éstas, a diferencia de lo ocurrido con otras publicaciones en tiempos pretéritos, no se ventilaban en las páginas de Cabildo.

\section{Las coordenadas ideológicas}

Los elementos que conforman el núcleo "duro" del pensamiento de quienes publicaban Cabildo no son en manera alguna nuevos; se trata del despliegue de una serie de ideas cuyas raíces pueden detectarse en un pasado a veces lejano, que se actualizan y reelaboran (relativamente) a los efectos de enfrentar la conflictiva realidad argentina del momento. Por esta razón, nos limitaremos a sintetizar los aspectos principales de su ideario; en la coyuntura que se inició en marzo de 1976, el nacionalismo católico por medio de su principal órgano de prensa renovó, al igual que en otras intervenciones militares, su esperanza de que los gobernantes pusieran en práctica sus propuestas. No obstante, ello no implicaba cambios sustanciales en su manera de entender el mundo.

\section{a) Una teología política}

Creemos que un punto de partida adecuado para iniciar el análisis de las bases del pensamiento de Cabildo es definirlo como una "teología política"; es decir, como un intento de legitimar una determinada praxis política a partir de una doctrina religiosa.

Esta doctrina religiosa, de claro sesgo tradicionalista, ${ }^{7}$ destaca la existencia de un "orden natural" basado en valores absolutos, que proviene de

6 Al referirnos a cada artículo se indicará el nombre del autor, cuando sea firmado por éste.

7 Para conocer los principios del pensamiento tradicionalista, es fundamental Pradera, Víctor: El Estado nuevo, Cultura Española, Madrid, 1935. 
un orden sobrenatural y pende de éste "como la materia de la forma, como la consecuencia de la causa, como lo accesorio de lo principal". ${ }^{8}$ Por lo tanto, la providencia divina es la base de todo lo existente; el mundo humano descansa en un orden eterno, y toda ley humana en la ley eterna. Ese "orden natural" se ha constituido a los efectos de la realización del bien común, asignando "a cada uno su sitio en función del principio del Orden". ${ }^{9} \mathrm{El}$ "sitio" que ocupa cada uno en la sociedad está establecido en función del todo social preexistente", de una "tradición heredada" que debe ser respetada. El Estado constituye "la unidad totalizadora y perfecta en su orden, armónica y adecuadamente limitada por las sociedades intermedias, en cuyo ámbito se desarrolla la vida de la Nación". ${ }^{10}$

Desde esta perspectiva, la Historia consiste en el desenvolvimiento de la ley divina y depende de la capacidad del hombre para comprenderla y seguir sus preceptos. No obstante, son muy claras sus limitaciones, al tratarse de un ser imperfecto y débil: por una parte, no está en condiciones de entender en forma cabal el plan de la Providencia; por otra, como está dotado de libre albedrío, puede caer en el error y en el pecado.

Este último punto es importante, ya que parte de una visión pesimista del hombre, quien munido exclusivamente de su razón está incapacitado para distinguir entre el bien y el mal, por lo que es preciso la guía de la religión.

Por lo tanto, y con riesgo de caer en alguna reiteración, las sociedades humanas han logrado conformar ese "orden natural" cuando su comportamiento sigue las reglas impuestas por la revelación divina; fuera de ellas impera el error.

\section{b) Reivindicación de la Edad Media}

El "orden natural" al que hacen referencia fue alcanzado durante la Edad Media, verdadero momento de plenitud en el que imperaban los valores absolutos, cuando el hombre estaba subordinado a principios superiores y no osaba cuestionar el mundo en el que vivía: "antes la Tierra era lo grande y todo giraba a su alrededor. Y era verdad, en un sentido más

\footnotetext{
8 Riva, Álvaro: "Sin dudas ni remordimientos", Cabildo, N. ${ }^{\circ}$ 45, Buenos Aires, 1981.

9 Ibarguren, Federico: "Liberalismo y bien común católico", Cabildo, N. ${ }^{\circ}$ 1, Buenos Aires,

10 M.C: "En el camino de las utopías políticas", Cabildo, N. ${ }^{\circ}$ 10, Buenos Aires, 1977.
} 1976. 
amplio que el matemático, como que incluía la vida". ${ }^{11}$ El universo medieval "era por entero teofanía, es decir, manifestación de Dios y jerarquía". ${ }^{2}$ Las normas tradicionales y de derecho natural eran acatadas por los gobernantes y el pueblo como la mejor garantía de las libertades y de los derechos. La igualdad que se defiende no es, en manera alguna, la igualdad ante la ley o la igualdad política; se trata de la igualdad "por virtud de la Creación". ${ }^{13}$

En rigor de verdad, la Edad Media no era estrictamente considerada como un período histórico sino, en cambio, una constante, un ideal alcanzado (supuestamente) en la Tierra, en el que el hombre se sentía vinculado con la realidad divina, "única roca eterna donde el pie no vacila".

Sin embargo, ese mismo hombre, por medio del despliegue de su subjetividad, se rebeló contra el orden tradicional, a la búsqueda de una explicación del mundo y de una organización de la sociedad que no estuvieran sujetas a un Dios todopoderoso de presencia constante. En ese momento histórico, que se inició "con la escolástica degradada de Occam”, emergió lo que "algunos textos pontificios y muchos escritores tradicionalistas llaman Modernidad". ${ }^{14}$

\section{c) La ruptura de la Modernidad}

Desde la perspectiva del pensamiento tradicionalista, el proceso histórico de la Modernidad puede resumirse en "la transferencia histórica de unas estructuras sistemáticas de raíz teológica a principios normativos de carácter inmanente". ${ }^{15} \mathrm{Su}$ descripción es sintetizada en un artículo escrito por el general Abdel Vilas, que de esta manera establecía un vínculo significativo entre los militares en el poder y quienes publicaban la revista.

En su explicación del desarrollo de la Modernidad, Vilas afirma que surgió al amparo de "reyes disolutos, ideólogos divorciados de la realidad, nobles decadentes y burgueses ávidos de dinero". ${ }^{16}$ Sus pasos sucesivos fueron: la Reforma Protestante en el siglo XVI, que atacaba la unidad

\footnotetext{
11 Riga, Carlos: "Las cosas de la vida", Cabildo, N. ${ }^{\circ}$ 2, Buenos Aires, 1976.

12 González Cuevas,: Acción Española..., pág. 347.

13 "Día de la Raza", Cabildo, N. 3, Buenos Aires, 1976.

14 Riva: . "Sin dudas...".

15 González Cuevas : Acción Española..., pág. 347.

16 Vilas, Edgardo: "Reflexiones sobre la subversión cultural. General Abdel", Cabildo, N. ${ }^{\circ} 9$, Buenos Aires, 1977.
} 
metafísica cristiana; "el idealismo, el racionalismo y el empirismo - verdadera trilogía diabólica_-" en el siglo XVII, a partir de los cuales sería deshecha la "filosofía perennis" de Occidente, abriendo el camino para que, un siglo más tarde, la Revolución Francesa destruyera el "orden político tradicional". ${ }^{17}$ De esta manera, el hombre moderno pierde la noción de la solidez y la inmutabilidad del mundo; el espíritu ya no se siente vinculado a ningún orden totalizante: utilizando la expresión de uno de los pensadores tradicionalistas más apreciados, "humanismo y relativismo son palabras sinónimas". ${ }^{18}$

\section{d) Crítica del liberalismo y de la democracia}

La consecuencia principal del proceso de decadencia en el que se ha sumergido la civilización occidental la constituye el triunfo del liberalismo, que en el terreno económico, "con su monstruosa concepción de una economía autónoma y desorbitada ha engendrado al gigantesco capitalismo", ${ }^{19}$ y que en el ámbito político ha consistido esencialmente en "haber separado la política de la realidad". ${ }^{20}$ De esta manera, el "orden natural" proveniente de la Edad Media, conservado y mejorado por la tradición, ha sido sustituido por un "orden esquemático ideal, apriorístico". ${ }^{21}$ Justamente, la revolución francesa es la que abre el camino a la utopía por excelencia del siglo XIX, la democracia.

En la nueva sociedad dominada por el liberalismo, el Estado se convierte en la "confluencia de los intereses y apetitos individuales", ${ }^{22}$ limitándose a garantizar "que cada uno disfrute lo suyo sin perturbar al otro". ${ }^{23} \mathrm{Al}$ carecer de misión trascendente, el Estado liberal requiere la existencia de los partidos políticos, que constituyen "la concreción práctica - y trágica - de la dispersión de la vida política". ${ }^{24}$ "La voluntad política del Bien Común es reemplazada por la competencia por el poder". ${ }^{25} \mathrm{Y}$ en ese ámbi-

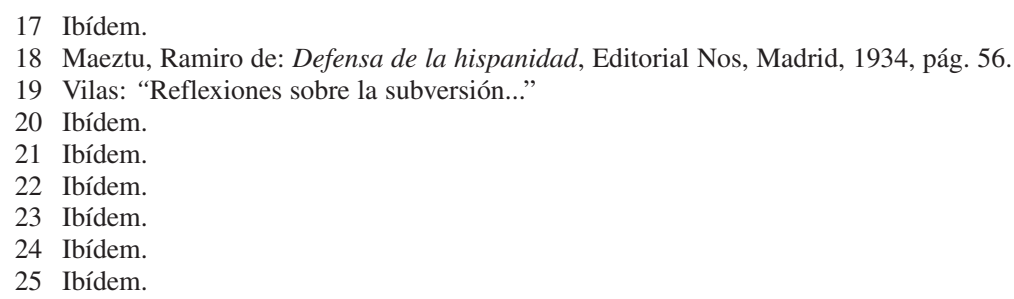


to dominado por la democracia, "en el que no hay partes que se ordenen al todo, pues ese todo ya no existe", ${ }^{26}$ se crean las condiciones para el triunfo del marxismo. Recogiendo una larga tradición del pensamiento contrarrevolucionario, no se plantea una distinción radical entre liberalismo, democracia y socialismo; constituyen tres formas de manifestación de una misma idea, "la autonomía de la conciencia humana". ${ }^{27}$

La agonía de la democracia constituye uno de los temas recurrentes de la revista "agonía sólo similar por lo definitiva e irreversible a la del Antiguo Régimen". ${ }^{28}$ Para el caso europeo, un colaborador francés, el conocido escritor de extrema derecha Maurice Bardeche, no duda en sostener que "la derrota de 1945 había destruido a Europa. Treinta años de democracia liberal han convertido al residuo de Europa que nos quedaba en un muñón purulento". ${ }^{29}$ Adhiriendo a quienes dedican sus esfuerzos a negar el Holocausto - "la leyenda de las atrocidades alemanas y de los campos de concentración" - destaca que "se somete a un ostracismo odioso a todos los regímenes que tratan de restaurar la autoridad del Estado y la primacía del interés público"..$^{30}$ La vigencia de la democracia en la segunda posguerra se constituye entonces en una posibilidad aprovechada por el marxismo, hasta el punto que "hoy el pluralismo democrático se ha convertido en la carta de ciudadanía del marxismo en el mundo llamado libre". ${ }^{31}$

En cuanto a la visión de la historia argentina, se afirma que el triunfo del liberalismo a partir de la batalla de Caseros - "la herida crucial de la Nación" - ${ }^{32}$ y la instauración de la democracia desde la promulgación en 1912 de la Ley Sáenz Peña han sido los hitos fundacionales de un largo proceso que culmina en el período 1973-76 con el peligro de "disolución nacional" surgido de la convergencia de la "democracia partidocrática" con la subversión marxista.

Por lo tanto, la tan prolongada decadencia argentina proviene de haber errado el camino; ¿cuál era éste? El que le marcaban sus raíces hispánicas.

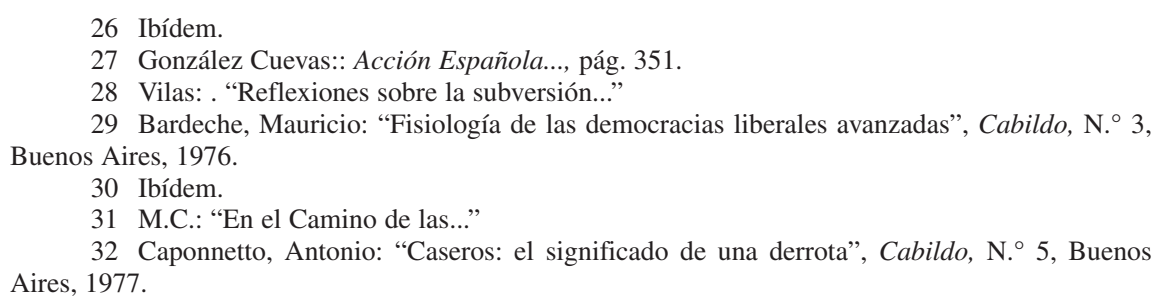

32 Caponnetto, Antonio: "Caseros: el significado de una derrota", Cabildo, N. ${ }^{\circ}$ 5, Buenos 


\section{e) Reivindicación de la hispanidad}

La España de la gesta americana constituye el legado espiritual, "la estructura fundamental de nuestro devenir histórico". ${ }^{33} \mathrm{Y}$ esa gesta es la culminación de un proceso varias veces secular, la Reconquista. Su visión está en perfecta sintonía con el nacional-catolicismo hispánico: "no es solamente la recuperación del ámbito geográfico; es la formación de su ser nacional impulsado por la fe católica" ${ }^{34}$ En su proceso de expansión, España llegó a América y su tarea de evangelización — lejos de cualquier cuestionamiento - fue el resultado de "un plan espiritual de soberana grandeza". ${ }^{35}$

La afirmación de los vínculos de la nación argentina con la tradición española es una constante, y llega hasta el extremo de poner en cuestión parte del proceso que culminó con la independencia: "rotos los vínculos espirituales que se llamaron 'cadenas', hemos deambulado por el mundo a la deriva, con remedos o imitaciones de mala factura". ${ }^{36}$

La tradición hispánica es entonces la que recoge la Argentina como nación y, fundamentalmente, ésa es la tradición verdadera cuyos valores es preciso retomar, no "la 'tradición' liberal que nos inventó la generación del 80: laicista, atea, demócrata, economicista. Es decir 'tradición moderna"'. ${ }^{37}$

\section{f) Visión conspirativa de la historia contemporánea}

Un perfil ideológico así de claro está acompañado de tópicos que también resultan habituales en el nacionalismo, como la conspiración judeomarxista y masónica. Abundan las referencias a esta cuestión, por lo que nos limitaremos a citar unas pocas lo suficientemente ilustrativas.

La protesta ante las acusaciones de antisemitismo formuladas en contra de la revista se fundamentan en el argumento de que la oposición a los judíos "emerge de la perenne enemistad entre Israel y Cristo, entre la Sinagoga y la Iglesia, entre el judío disperso, errante y desarraigado, y las naciones cristianas". ${ }^{38}$ Pero además, “¿quién puede negarnos con seriedad,

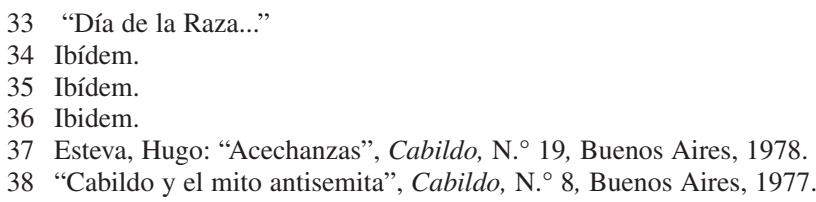


la complicidad manifiesta del Judaísmo con el Comunismo, ampliamente documentada en tantas y tan trágicas experiencias históricas? (Recuérdese a quiénes financió la Revolución Rusa) ¿Quién puede negar la instrumentación del Comunismo como elemento ideológico de destrucción por parte del Imperialismo internacional del Dinero?". ${ }^{39}$

En relación con la específica situación argentina, tanto el Ministro de Economía del último gobierno de Perón, José Ber Gelbard, como el financiero David Graiver se constituyeron en verdaderas "bestias negras" de la revista, responsables de todos los males que corroen al país. ${ }^{40}$ En algún momento, se llega al extremo equiparar el "caso Graiver" — su muerte en un accidente en circunstancias a las que se rodeó de misterio- con el caso Dreyfus. ${ }^{41}$

En cuanto al tan trillado tema masónico, un artículo publicado con motivo de la situación argentina es buena ocasión para afirmar que "detrás de cada una de las revoluciones comunistas — promoviéndolas y afianzándolas - han estado desde siempre, unidos en el mismo odio, los poderes masónicos y judíos". ${ }^{42}$

\section{La propuesta de Cabildo}

Identificados los elementos que constituyen el acervo ideológico de la revista, cabe preguntarse cómo esos principios se relacionaban con una práctica concreta de gobierno. Para ser más claros, ¿cuáles son los rasgos de esa Revolución Nacional a la que frecuentemente se hace referencia?

Afortunadamente nos encontramos con un par de formulaciones explícitas, dadas a conocer bajo los títulos de "Las Leyes de la Revolución Nacional", ${ }_{43}$ con la firma de su director, y de "Principios Doctrinarios del Movimiento Nacionalista de Restauración". ${ }^{44}$ Ambas expresiones programáticas se dieron a conocer en una coyuntura muy específica — segunda mitad de 1981 y comienzos de 1982 - caracterizada por la crisis económi-

39 Ibídem.

40 Por ejemplo, "Las cenizas de David", Cabildo, N. ${ }^{\circ}$ 3, Buenos Aires, 1976.

41 "Editorial", Cabildo, N. ${ }^{\circ}$ 7, Buenos Aires, 1977.

42 Capponetto, Antonio: "La ofensiva masónica", Cabildo, N. ${ }^{\circ}$ 9, Buenos Aires, 1977. Aires, 1981

43 Curutchet, Ricardo: "Las leyes de la Revolución Nacional", Cabildo, N. ${ }^{\circ} 44$, Buenos

44 "Principios doctrinarios del Movimiento Nacionalista de Restauración", Cabildo, N. ${ }^{\circ} 49$, Buenos Aires 1982 . 
ca y política que se desencadenó a partir de la asunción como presidente del general Roberto Viola en reemplazo de Videla, pero sobre todo por la clausura del proyecto económico que lideró Martínez de Hoz desde el ministerio de Economía, que se intentó superar finalmente con el reemplazo de Viola por Galtieri y con la conformación de un equipo económico de signo inequívocamente liberal, encabezado por Roberto Alemann. La decisión adoptada generó, naturalmente, la reacción de quienes publicaban la revista que se propusieron - como veremos- organizar una fuerza política que siguiera los principios que se defendían en ella.

En ambos textos se plasma el ideario del nacionalismo a la altura de principios de los 80, aplicado a la situación concreta de la República Argentina. Todas las referencias provienen de alguno de estos dos "programas".

Además de insistirse una vez más allí en la reivindicación de la tradición, la "raíz católica e hispanoamericana de la Patria", en el desprecio del liberalismo democrático, "un artificial andamiaje político, filosófico, jurídico, social, económico e incluso espiritual", y en el "rechazo frontal de las fórmulas del capitalismo liberal tanto cuanto del capitalismo de estado marxista", aparecen los elementos constitutivos de la comunidad a la que aspiran:

- Estará gobernada por una dictadura, "encarnada en una personalidad central y un equipo de hombres", capaz de llamar a "la empresa en suspenso de la Reconquista de la Argentina".

- Se apuntará a la afirmación de un "Estado ético, apto para el logro de la Revolución Nacional ordenada al Bien Común". La subordinación de lo político a lo ético, pero además de lo ético a lo teológico, constituye una de las bases del tradicionalismo católico que expresa el nacionalismo de los hombres de Cabildo.

- Esta concepción del Estado debe "fundarse en el reconocimiento de las instituciones naturales de la sociedad: familia, asociación profesional, municipio, provincia y región, las cuales constituyen la base de toda representación auténtica y orgánica".

- La política social parte del rechazo de "toda concepción que promueva el enfrentamiento social y su consecuencia, la lucha de clases". Para ello, por una parte el Estado "deberá asegurar al trabajador de cualquier especie la obtención de una retribución, que le permita vivir decorosamente, la seguridad en su empleo y la igualdad jurídica respecto de sus empleadores". Por otra, la solidaridad social conduce al agrupamiento de los tra- 
bajadores "mediante asociaciones que representen sus intereses y se integren con las demás ramas y jerarquías laborales —obreros, técnicos y patrones - en forma vertical, favoreciendo de ese modo el acuerdo social y el amparo de las fuentes de trabajo y producción esenciales para la Nación".

- La política económica está encuadrada en su concreción por el "proyecto político nacional", por lo que "debe servir a la Sociedad y a la Nación como instrumento del Bien Común.

Para cumplir con esa tarea se hace imprescindible: a) la "efectiva independencia económica que, al desligarnos de las presiones del capitalismo financiero internacional y de sus agentes nativos, haga realidad la nacionalización de nuestra economía", b) la revalorización del "papel del Estado en la economía, por la aplicación sustantiva y no meramente supletoria del principio de subsidiariedad, claramente enseñado por la Doctrina Social de la Iglesia"; c) la implantación de un "decidido proteccionismo industrial, correlativo a rígidas normas referentes al destino del beneficio"; d) el rechazo enérgico de "la economía de lucro", lo que implica que "la economía debe estar al servicio de la persona - materia y espíritu- y no de un conjunto de hombres que, mediante el manejo inmoral de los medios de comunicación, promuevan artificialmente un desenfrenado hábito consumista".

En resumen: la economía debe "asegurar la justicia distributiva, fomentar la propiedad privada — incluida la de los medios de producción-, potenciar al país para asegurar su independencia, proveer de fuentes de trabajo, hacer posible la honestidad personal y eliminar los factores que degradan el nivel ético general".

- En cuanto a la política exterior, ésta debe partir de ciertas premisas: 1) La Argentina es un país occidental "y no del Tercer Mundo, entendiéndose que Occidente es un orbe histórico-cultural, de signo espiritual cristiano, sin concreción o liderazgo en el mundo actual"; 2) En defensa de los valores espirituales occidentales debe actuar con firmeza e incluso "asumir la iniciativa" en todo lo referente a la amenaza del imperialismo comunista; 3) Dado que las actuales organizaciones de vinculación internacional no responden "a las exigencias del derecho de gentes de las naciones cristianas", la permanencia en ellas "no se estimará como un acto necesario o imprescindible"; 4) El enemigo histórico es Brasil (no adversario, enemigo), a quien, por tanto, la Argentina "debe disputarle todos los espacios en la región y procurar excluirlo del Atlántico Sur y de la Antártida"; 
5) Debe ser misión propia del país "la de proyectar su Política Nacionalista en la América hispana, colaborando con todos los gobiernos agredidos por la guerrilla marxista"; 6) Respecto de las vinculaciones con la URSS, un tema caliente en ese momento como consecuencia de las relaciones comerciales anudadas, la política "debe ser de rechazo de todo acuerdo económico, financiero, técnico o cultural, que comprometa la límpida conducta patriótica y occidentalista de la República"; 7) Frente a los contenciosos con Chile y Gran Bretaña, es preciso "una política del hecho consumado, es decir, la recuperación militar de las tierras ocupadas (...), que terminaría concluyente y definitivamente toda cuestión".

- Finalmente, la política cultural y educativa plantea como objetivo "la restauración de la cultura", para la cual deben contribuir tanto la educación como la censura.

La nueva política educativa debe reorientarse a fondo para producir "un despertar de la conciencia nacional y católica". En todos los niveles de la educación es preciso "estimular el sentido de pertenencia y arraigo a la comunidad histórica nacional frente a las acechanzas foráneas". A su vez, la censura sobre los medios de comunicación "debe significar la erradicación definitiva de la inmoralidad y la estupidez". Pero, sin duda, la clave de la política educativa es la siguiente: "El Nacionalismo no debe renunciar a su objetivo de extirpar de nuestra Nación la peste del laicismo y con ella la Ley de Enseñanza Laica, devolviendo a la educación el sentido religioso que le es esencial y, además, el propio de nuestra tradición".

Con un programa de este tipo, era ciertamente difícil la conciliación, incluso para una dictadura militar como la del Proceso.

\section{Cabildo frente al Proceso}

No cabe duda de que el 24 de marzo de 1976 marcó un punto de ruptura en la historia argentina. Si bien desde hacía varias décadas la oscilación entre gobiernos civiles y militares se había convertido en una dramática normalidad en el devenir político argentino, esta nueva intervención significó un salto cualitativo en el intervencionismo castrense, con efectos devastadores para la sociedad en su conjunto. El hecho de que los militares en el poder se plantearan como objetivo una "refundación" de la República, condenando explícitamente el camino seguido por el país prácticamente desde 1930, si bien constituía un segundo intento de este tipo, tras la fallida experiencia 
de la "Revolución Argentina" de 1966 encabezada por el general Juan Carlos Onganía, las circunstancias en las cuales la Junta Militar tomó el poder diez años más tarde marcaban la existencia de una realidad diferente y la necesidad de poner en práctica instrumentos antes no utilizados para la tarea de rectificar el rumbo seguido en la historia reciente.

En particular, el objetivo de los militares de restaurar el orden acabando con la democracia dio lugar a que los partidarios del nacionalismo católico, criticado por éstos desde los años 20, renovaran como en 1930, 1943, 1955 y 1966 sus esperanzas de instaurar las bases de una Nación Católica. ${ }^{45}$ La prédica fue reanudada con mayor ímpetu; había llegado otra vez "la hora de la espada", y las circunstancias parecían más favorables que nunca. Retomó entonces con fuerza la actividad iniciada a fines de la década de 1920 en los ámbitos eclesiásticos y militares, afirmada en la puesta en práctica de un proyecto de reformulación de la identidad nacional, acompañado de la creación de un nuevo orden social.

Como se ha dicho, cuando se produjeron los acontecimientos de marzo de 1976, Cabildo estaba clausurada por decisión del gobierno peronista, por lo que fue recién en agosto cuando tuvieron ocasión de manifestarse en relación con el momento político.

El Editorial del primer número no ahorraba elogios hacia el hecho de que los militares hubieran derrocado al gobierno: "de las seis irrupciones militares en el plano del poder civil ocurridas en los casi cincuenta años, ninguna tan necesaria ni ansiada" ${ }^{46}$ No se trataba de un comentario aislado; en el número siguiente se afirmaba enfáticamente que "el 24 de marzo, el Estado recuperó la dignidad y la Nación su honor". ${ }^{77}$

No obstante, ya en esos momentos se llamaba la atención sobre el hecho de que las fuerzas armadas triunfantes no debían autolimitarse "al ejercicio de una operación simplemente higienizadora del Estado y sólo afanada por reordenar aquella misma partidocracia culpable". ${ }^{48}$ La esperanza de los hombres de Cabildo residía en que esta intervención militar fuera la última, procediendo a acabar con la democracia en la Argentina, y éste era el punto central: la realidad de "que en el proceso abierto en 1973 se ha hundido para siempre la democracia electoralista, universal y anónima". ${ }^{49}$

45 Zanatta, Loris: Del Estado Liberal...

46 Curutchet, Ricardo: "Editorial", Cabildo, N. ${ }^{\circ}$ 1, Buenos Aires, 1976.

47 Curutchet, Ricardo: "Editorial", Cabildo, N. ${ }^{\circ}$ 2, Buenos Aires, 1976.

48 Curutchet: "Editorial", Cabildo, N. ${ }^{\circ} 1$.

49 Ibídem. 
Por lo tanto, en principio, se apostaba por "el pleno éxito de esta secuencia histórica". ${ }^{50}$ A partir de la toma del poder, los militares habían iniciado la tarea de colocar a la Argentina en el "camino hacia el orden". ${ }^{51}$ Pero no se trataba solamente de eso; ellos insistían en la "necesidad de insertar a la república en un orden nuevo". ${ }^{52}$

Pero era también aquí donde empezaban a manifestarse las diferencias. Todas las medidas orientadas hacia el tan anhelado "restablecimiento del orden" eran aplaudidas. Incluso, como veremos, se justificaban las violaciones a los derechos humanos; la cuestión residía en que se les reclamaba algo más, y desde esa perspectiva no podían dejar de aparecer importantes divergencias.

A los efectos de sistematizar la exposición hemos seleccionado los principales temas de fricción, que se van agudizando a medida que el Proceso fracasaba en todos sus emprendimientos. No obstante, es preciso destacar la existencia de una divisoria de aguas que es la guerra de las Malvinas, ya que como consecuencia del intento del 2 de abril de 1982 desde la redacción de la revista se percibe la posibilidad de que los militares adopten el "rumbo correcto". Por supuesto, esa corta "primavera" duró poco; el desenlace del conflicto condujo a la ruptura definitiva con el gobierno; a partir de ese momento las críticas se tornan irreversibles, en tanto el retorno a la democracia constituye para ellos una derrota mayúscula, por lo que no resulta extraño que Videla termine siendo calificado como "El máximo culpable".

\section{a) La construcción de un "orden nuevo"}

Desde el principio, la crítica de Cabildo al gobierno del Proceso se centró en la falta de una línea política e ideológica capaz de llevar a buen puerto las (supuestas) ansias revolucionarias existentes el 24 de marzo. Los nacionalistas esperaban una señal de los militares en el poder, dado que "esta actitud según la cual el gobierno no se permite ninguna definición ideológica, no puede ser de largo alcance ya que le resulta insuficiente a las propias fuerzas armadas. Su temor y desprecio por la política no

50 Curutchet: "Editorial", Cabildo, N. ${ }^{\circ} 2$.

51 Ibídem.

52 Ibídem. 
pueden llevarlos a la convicción de que se accede al poder para no hacer política, sino precisamente para hacerla pero, eso sí, bien". ${ }^{53} \mathrm{El}$ intento consistía en influir sobre el Proceso para que éste adoptara, sin más retrasos, la doctrina nacionalista, la única capaz — según Cabildo — no sólo de restaurar el orden sino también de imponer uno nuevo: "la lucha más importante, la lucha contra el marxismo como concepción del mundo sólo puede hacerse seriamente desde otra concepción del mundo que sea por lo menos igualmente fuerte, enérgica, ambiciosa" y esta concepción no era otra que la "mística nacional, jerárquica fundada en los valores del espíritu", ${ }^{54}$ es decir, la mística del nacionalismo católico. Para su consecución se necesitaba una mano firme, la figura del dictador, ya que "el nacionalismo... no puede ser moderado sino absoluto, total...";55 interpretando las actitudes del gobierno como manifestaciones de moderación, fueron tomando distancia respecto de él.

En la definición ideológica, la identificación del enemigo jugaba un papel preponderante. En torno a él gira el discurso de Cabildo: "descubrir a nuestros enemigos, denunciarlos y derrotarlos" ${ }^{56}$ era el imperativo. El tono acusador se desprende de la premisa de que siempre hay un responsable de los males de la patria. Por ello en su identificación correcta está el primer paso de la construcción nacional.

El enemigo era tanto interno como externo, y lo percibían en las naciones que atentaban contra el país y en las ideologías foráneas que penetraban en la sociedad, consideradas ajenas a la nación y peligrosas por demás. En la ya antigua tradición del pensamiento contrarrevolucionario, no se planteaba una distinción radical entre liberalismo, democracia y socialismo, por ser las tres manifestaciones de la intromisión foránea, de lo antinacional. El enemigo se construía en torno a la tríada capitalismo-judaísmo-marxismo, y los defensores del ser nacional debían unirse para identificarlo y destruirlo. Los frecuentes ataques realizados desde la revista a personalidades del mundo judío como Jacobo Timerman o a David Graiver responden a esta lógica.

La falta de coincidencias con el gobierno del general Videla los llevó a una crítica que se hizo cada vez más dura, fundamentalmente originada en las declaraciones de miembros del gobierno o de las fuerzas arma-

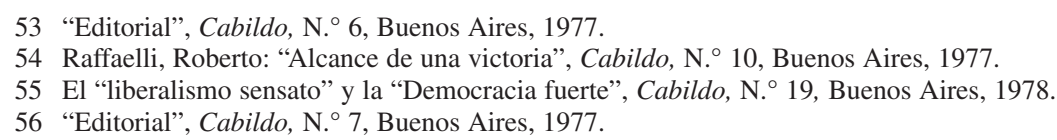


das respecto de un eventual retorno a la democracia (en general con el agregado de "moderna"). Pero esta actitud, aun con toda la dureza con que en ocasiones se manifestaba, no significaba una ruptura total; por el contrario, en ocasión de aproximarse el reemplazo de Videla por el general Roberto Viola, se renovaron las apelaciones a los militares para que en lugar de un "proceso", pusieran en marcha "un movimiento coherente que termine con los males y vicios heredados y originales, que se arrastran del pasado y que nacen en cada nueva etapa" ${ }^{57}$ Esto implicaba, nada más y nada menos, que "una revolución que destruya a los enemigos y no que los reacomode". ${ }^{58}$

Sin embargo, ante las perspectivas emergentes de la designación de las nuevas autoridades, se retornó a la idea de "que el Proceso gobernó contra el país", ${ }^{59}$ y que su gestión podía resumirse como la "crónica de un fracaso". ${ }^{60}$

La necesidad de actuar políticamente para rectificar el rumbo del Proceso llevó a que durante el período en el que estuvo conducido por Viola se iniciara una actividad que iba más allá del ámbito periodístico, apuntando hacia la conformación de un movimiento nacionalista, lo que se concretó en el mes de noviembre. Con independencia de las propuestas, de las que hemos dado cuenta en el apartado correspondiente, el título de portada de uno de los ejemplares de esa época resumía los planteos mejor que cien programas: "La única opción: anarquía de los partidos o dictadura nacional". ${ }^{61}$

Este accionar del nacionalismo se verificó en un escenario atravesado por la crisis que afectó al gobierno de Viola y que culminó con su desplazamiento, al designarse en su reemplazo al Comandante en Jefe del Ejército, Leopoldo Fortunato Galtieri, a fines de 1981.

El sesgo ultraliberal del nuevo gabinete, sintetizado en la figura de Roberto Alemann, uno de los iconos del liberalismo vernáculo, al frente de la cartera de Economía, condujo a que se agudizaran las críticas y se potenciara la descalificación de los militares en el poder. No obstante, esa situación estaba en condiciones de revertirse, y los sucesos de abril de 1982 lo demostraron.

57 "Editorial", Cabildo, N. ${ }^{\circ}$ 30, Buenos Aires, 1979.

58 Ibídem.

59 "Editorial", Cabildo, N. ${ }^{\circ}$ 36, Buenos Aires, 1980.

60 Pacheco, Javier: "Balance político (1976-1981)", Cabildo, N. ${ }^{\circ} 41$, Buenos Aires, 1981.

61 Cabildo, N. ${ }^{\circ} 41$, Buenos Aires, 1981 


\section{b) La represión y los derechos humanos}

A partir de la concepción, sostenida también por los dirigentes del Proceso de Reorganización Nacional, de que el país se hallaba en estado de guerra interna, para los hombres de Cabildo era preciso "encarnar esa convicción en la conducta total del Estado"62 y, por lo tanto, cualquier acción estaba justificada. La acusación de violación de los derechos humanos era básicamente denunciada "como el pivote de una vasta y nada sutil acción de la izquierda internacional contra la estabilidad del gobierno militar". ${ }^{63}$ La posición se resumía así: "no es el caso demostrar que la Argentina y sus Fuerzas Armadas no violan los derechos humanos sino de rechazar la defensa de los derechos humanos — tal como se la plantea- por intrínsecamente subversiva y por basarse en una ideologización condenable" ${ }^{64}$

Desde esa perspectiva, no había que dar cuenta a nadie de lo que ocurría fronteras adentro del país: las gestiones del gobierno de Videla destinadas a modificar la imagen del país frente al exterior constituían simplemente claudicaciones por parte de quienes, como las fuerzas armadas, tenían todas las razones para actuar como actuaron; de lo que se trataba era de "salvar los derechos históricos de la Patria". ${ }^{65}$ Por lo tanto, acontecimientos como la llegada en septiembre de 1979 de la Comisión Interamericana de Derechos Humanos de la OEA, son calificados como "una intromisión consentida". ${ }^{66}$

Pero si bien la subversión fue atacada sin tregua por los militares en el poder suscitando el explícito apoyo de la revista, "...finalmente el golpe se hará cruzada y la represión la guerra justa" ${ }^{67}$ esto no era suficiente, ya que se pretendía además el aniquilamiento de esas ideas y no solamente de quienes las defendían. El cuestionamiento político provenía del hecho de que para los nacionalistas católicos la lucha antisubversiva se había limitado al plano militar, en el cual se obtuvo una bien recibida victoria, pero sin conquistar el terreno espiritual, era la conciencia donde consideraban que se libraría la batalla que llevaría a la victoria final. A pesar de las continuas persecuciones, la censura, etc., éstas no eran medidas suficientes para el

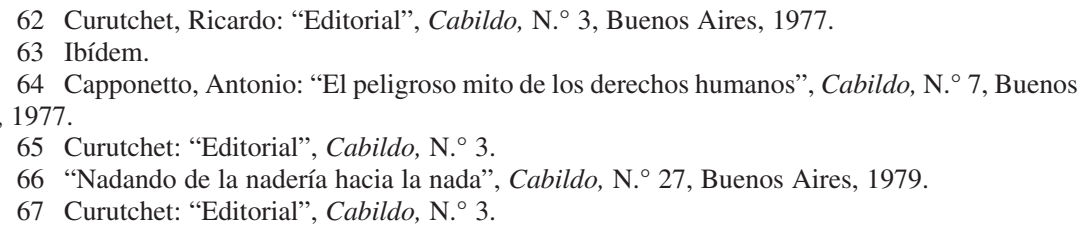


nacionalismo, que se había planteado como objetivo izar la bandera de la nación católica en el terreno ideológico-cultural.

La propuesta era entonces acabar con la subversión, entendiendo por tal "la revolución cultural" dentro de la cual "la guerrilla no es sino una 'parte' de ese 'todo". ${ }^{68}$ Ésta tenía múltiples definiciones: por ejemplo, "ha sido 'subversión' distribuir Bergman, Pasolini, Bertolucci y compañía; instaurar el desnudo en el escenario y la publicidad, promover la moda "unisex"." ${ }^{69}$

Por otro lado, las diferencias con el poder se acentuaron por la falta de convicciones por parte del Estado militar respecto de las "verdaderas" características del enfrentamiento, que dificultaron el desempeño de las Fuerzas Armadas: "en la guerra contra el marxismo hubo un ejército que combatió con honor, pero no hubo un Estado responsable que asumiera, como tal, la decisión de matar". ${ }^{70}$ Ante la pedida actuación a la luz del día y la aplicación de la pena de muerte el gobierno optó por la guerra en las sombras.

\section{c) La política económica}

Si bien los cuestionamientos a la economía se presentaban como una consecuencia de las críticas políticas, su fuerza no dejaba de otorgarles gravitación propia. Se enfatizaba que el plan implementado iba a contrapelo de los objetivos que ellos le atribuían al Proceso de Reorganización Nacional. La gestión de José Alfredo Martínez de Hoz y su equipo fue crecientemente cuestionada y, tras su salida del Ministerio, las críticas subieron aún más de tono: "Nuestro disenso con la política económica oficial y nuestra falta absoluta de coincidencia con los pronósticos del jefe del equipo económico son el producto de una observación realista de los fenómenos económicos fundada sólo en el interés nacional". ${ }^{71}$

Las premisas sobre las cuales se asentaba la política económica llevaron a un enfrentamiento que se manifestó desde un principio y que fue en

68 Valdez, Demetrio: "Deber frente a los caídos: combatir la subversión para aniquilar la guerrilla", Cabildo, N. ${ }^{\circ}$ 2, Buenos Aires, 1976.

69 Ibídem.

70 Curutchet: "Editorial", Cabildo, N. ${ }^{\circ} 3$. Aires, 1977

71 "Desarrollo de la especulación sin desarrollo económico", Cabildo, N. ${ }^{\circ}$, Buenos 
ascenso en tanto algunos éxitos parciales — sobre todo la disminución de la inflación- no ocultaban un fracaso generalizado. Se compartía, en principio, la descripción de la realidad que había hecho Martínez de Hoz en su presentación, en particular el énfasis que puso en pasar de una economía de especulación a una de producción, pero rápidamente llamó la atención sobre las "graves contradicciones entre los propósitos enunciados y las medidas adoptadas". ${ }^{72}$

Por otra parte, en la medida en que el secretario de redacción, Juan Carlos Monedero, era funcionario del Banco Central y fue puesto a "disponibilidad" por el presidente del Banco mientras Martínez de Hoz era ministro, el cuestionamiento se caracterizó también por la denuncia de una serie de irregularidades surgidas en el proceso de apertura financiera y económica que se inició en 1977.

"Economía: un mandato de las FF.AA. no cumplido", ${ }^{73}$ es uno de los innumerables titulares en los cuales de enfatizaba que el plan económico implementado iba a contrapelo de los objetivos que ellos le atribuían al Proceso de Reorganización Nacional. Ya en marzo de 1978 advertían que, más allá de "las sanas intenciones de las Fuerzas Armadas", 74 la gestión económica se había saldado con un fracaso. Los análisis se realizaban desde la perspectiva de un nacionalismo económico que, sin mayores precisiones y con argumentaciones en las que abundaban las contradicciones, descalificaban el conjunto de la política económica al afirmar que se estaba realizando "un sacrificio sin razón, y peor aún, sin legitimidad". ${ }^{75}$

Las críticas continuaron luego del cambio de gabinete que acompañó a la salida de Videla de la presidencia, reemplazado por el general Roberto Viola, circunstancia que llevó también a los nacionalistas a aumentar su actividad política organizando, como se ha comentado, el Movimiento Nacionalista de Restauración, y se potenció durante la gestión de Leopoldo Fortunato Galtieri. La propuesta del ministro Alemann de privatización del subsuelo le dio pie para descalificar al liberalismo como corresponsable, junto al populismo, de los males del país. La etapa del Proceso encabezada por Galtieri pasó a ser el momento en que se ha "convertido en una herramienta del liberalismo". ${ }^{76}$ Aires, 1976

72 "Recesión para los argentinos, expansión para los especuladores", Cabildo, N. ${ }^{\circ}$ 1, Buenos

73 Cabildo, N. ${ }^{\circ}$ 14, Buenos Aires, 1978.

74 Ibídem.

75 Ibídem.

76 "Editorial", Cabildo, N. ${ }^{\circ}$ 49, Buenos Aires, 1982. 
Además, la circunstancia de que Alemann fuera el representante de la banca suiza en la Argentina sirvió para descalificar su accionar durante la guerra del Atlántico Sur, reivindicando a través de una serie de artículos firmados por Walter Beveraggi Allende, uno de los principales economistas de orientación nacionalista, la necesidad imperiosa de implementar "una economía de guerra".

Por lo tanto, y para resumir: en la visión de Cabildo, la gestión revolucionaria en el terreno económico jamás llegó a concretarse, ya que el plan elaborado por los círculos liberales allegados al poder apuntaba a establecer una estructura productiva basada en las señales lanzadas por el mercado y una presencia destacada del capital extranjero.

\section{d) La política exterior}

La dictadura militar fue una expresión nítida de las facetas contradictorias que experimentaba en esos días la política exterior argentina. Frente a lo que se consideraba una conducta errática, Cabildo estableció, por supuesto desde su visión, cuáles eran esos desvíos e intentó por todos los medios exhortar al gobierno a marchar por el que, para ellos, era el camino correcto. Más allá del posicionamiento general que se ha expuesto en la revisión de su programa - que incluía un rechazo a las organizaciones internacionales que cuestionaban la política represiva del gobierno argentino - a lo largo del período que estamos considerando las demandas nacionalistas se manifestaron en varios terrenos. En principio, Brasil era considerado el enemigo histórico en la región y sus obras hidráulicas en la Cuenca del Plata - fundamentalmente la decisión de construir la represa de Itaipú, a la que se le atribuía un impacto negativo sobre el territorio argentino - se interpretaban en términos de agresión, que debían ser objeto de respuesta por parte del gobierno. Por ello, inicialmente se saludó con agrado que en la VIII Conferencia de Cancilleres de la Cuenca del Plata realizada a fines de 1976 el representante argentino afirmara que "no reconoce que Itaipú sea un hecho consumado". ${ }^{77}$

Pero el problema con Brasil se superpuso con una cuestión aun más perentoria: el conflicto con Chile por las islas situadas en el canal de Beagle. Cuando los militares tomaron el poder, la cuestión estaba desde

77 Moyano, Miguel Ángel: "La cuenca del Plata”, Cabildo, N. ${ }^{\circ}$ 4, Buenos Aires, 1976. 
1971 en manos en la reina de Inglaterra, que debía expedirse en condición de árbitro (y que lo hizo otorgando las islas en litigio a Chile). Descalificando todas las acciones realizadas por gobiernos anteriores, desde su reaparición Cabildo insistió en la necesidad de que "el Poder Ejecutivo debe declarar nulo lo actuado y debe hacerlo saber al tribunal que se ocupa del pleito para que lo paralice". ${ }^{78}$

Para ello se apela en principio "a la solidaridad necesaria en la lucha contra la guerrilla", ${ }^{79}$ para pedirle al gobierno chileno encabezado por Augusto Pinochet - un gobernante admirado por quienes publicaban la revista - una postergación en el juicio para explorar otras posibilidades.

El comportamiento de Cabildo se modificó de manera radical cuando en los primeros meses de 1977 se dio finalmente a conocer el fallo favorable a Chile; desde ese momento la actitud se volvió beligerante. Cuando el gobierno chileno respondió con reticencia a la propuesta argentina de una negociación bilateral - como es lógico dado el hecho de que sus posturas fueron mayoritariamente reconocidas por el árbitro-, la postura de la revista fue rotunda: "No queda otro camino para nuestro gobierno que el rechazo del laudo y la inmediata ocupación de los territorios cuestionados por Chile". ${ }^{80}$

En enero de 1978, momento en que el gobierno argentino decidió negar validez al pronunciamiento arbitral, Cabildo apoyó de manera inequívoca la postura, y en el número de febrero dedicó buena parte de sus páginas a tratar el tema, incluyendo artículos de nacionalistas como Federico Ibarguren, Alberto Asseff, o el profesor Federico A. Daus, quienes desde diferentes ángulos avalaban la posición adoptada por los militares.

Desde ese instante, la presión se tornó constante, y se intimó al gobierno para que actuara dejando de lado las negociaciones; la apelación a la guerra aparece fundamentada en la doctrina de la Iglesia: la insistencia en que "el pacifismo es anticristiano" ${ }^{81}$ era acompañada de una apelación "a aceptar el sacrificio de toda guerra justa para que nuestros hijos no puedan reprocharnos mañana el deshonor y la vergüenza". ${ }^{2}$

Hacia fines de 1978, el fervor nacionalista se manifestó en toda su beligerancia: la portada del número de noviembre unía los dos grandes

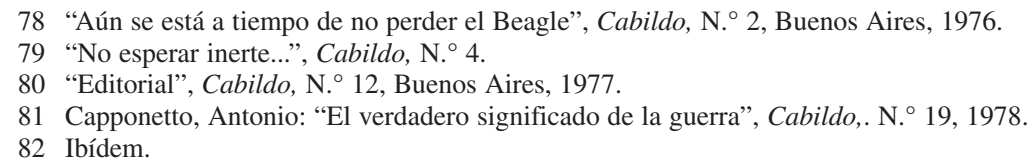


temas de la política exterior del momento: "Imperativos de Hoy. Ante Chile: recuperar ya todo lo usurpado. Ante Brasil: defender hasta el fin lo amenazado" ${ }^{83} \mathrm{Al}$ mes siguiente, la apelación fue mucho más directa: "Ni mediación ni injerencia foránea: cortar el nudo con la espada sin más pérdida de tiempo" ${ }^{84}$ Asimismo, en un recuadro se realizaba una "exhortación patriótica" a sus lectores para que "ante la grave emergencia internacional que vive la Patria, ofrezcan — cualesquiera sean su edad y sexo- sus servicios voluntarios a las Fuerzas Armadas de la Nación". ${ }_{85}$

El 8 de enero de 1979, luego de estar al borde de entrar en guerra, la Argentina y Chile firmaron el acta de Montevideo que sometía el entredicho a la mediación del Papa. La situación se presentaba difícil para Cabildo, en tanto era nada menos que la "Silla Apostólica" la que quedaba involucrada en el diferendo, pero su posición consistió en sostener que el estado de cosas existente no podía ser rectificado por el mediador, por más que éste se encontrara en disposición de "iluminar y enaltecer el ánimo de los negociadores en favor de un acuerdo levantado y justo". ${ }^{86}$ La postura era pues claramente combativa, ya que afirmaba que la decisión corría por cuenta de las partes en conflicto, y en ese caso, el hecho de que Chile hubiera ocupado las islas constituía un hecho consumado frente al cual sólo cabían actitudes fuertes - "el bloqueo, el desalojo, la intimación armada en el terreno mismo, etc." - ${ }^{87}$; como ninguna se ensayó, pese a la intervención papal, la Argentina marchaba "hacia una nueva pérdida territorial". ${ }^{88}$

A su vez, respecto del acuerdo firmado en octubre de 1979 con Paraguay y Brasil por la construcción de las represas de Itaipú y Corpus, Cabildo resume en una frase: "el día 19 de octubre de 1979 debe inscribirse como día de luto para la Argentinidad". ${ }^{89}$ La insistencia en describir con los tonos más negativos todas las negociaciones realizadas en los contenciosos con los países vecinos da cuenta sin duda de uno de los rasgos unánimemente atribuidos por los estudiosos a los nacionalismos exacerbados: la "demonización" del "otro"; la atribución a éste — situado siempre cerca— de las peores intenciones y el afán sistemático de perjudicarnos.

83 Cabildo, N. ${ }^{\circ}$ 20, Buenos Aires, 1978

84 Cabildo, N. ${ }^{\circ}$ 21, Buenos Aires, 1978.

85 "Exhortación patriótica", Cabildo, N. ${ }^{\circ} 21$.

86 "Chile triunfa con la ley del más fuerte", Cabildo, N. ${ }^{\circ}$ 22, Buenos Aires, 1979.

87 Ibídem.

88 Ibídem.

89 "Se consumó la tragedia", Cabildo, N. ${ }^{\circ} 29$, Buenos Aires, 1979. 
Finalmente, el Cardenal Antonio Samoré dio a conocer la propuesta papal el 12 de diciembre de 1980. La resolución, negativa para la Argentina, despertó abundantes críticas; "Ante la cuestión Austral: responder con un no a la propuesta del mediador", ${ }^{90}$ es el título de la portada del número siguiente a la presentación oficial de la propuesta del Vaticano. Esta reacción no implicaba un cuestionamiento a la figura del Papa, dado que "no es el Santo Padre el responsable de su propuesta, sino el Gobierno que la ha facilitado, alentado, sugerido o cuasi forzado con su anticipada rendición, con sus debilidades, concesiones y complacencias y otras variadas escapatorias para no cumplir con el deber que él mismo se había impuesto: el de 'tomar todas las medidas necesarias para la defensa de sus planes en la zona hasta el Cabo de Hornos". ${ }^{91}$

\section{e) La guerra del Atlántico Sur}

El 2 de abril de 1982, al producirse la invasión de las islas Malvinas, todas las críticas al Proceso que habían arreciado durante los meses anteriores quedaron en suspenso. El acontecimiento se vislumbró como una oportunidad para que se hallara el camino correcto. "Esta guerra es quizás nuestra última chance. Valdrá la pena morir por ella si nos purifica como nación". ${ }^{22}$ La necesidad de revalorizarla y terminar con una política de concesiones en el plano de la política exterior se tornó una demanda acuciante.

La recuperación de las islas fue vista bajo la óptica de que expresaba el genuino sentir del conjunto de la nación - "recuperar las islas es un acto para siempre" $-{ }^{93}$ y como el punto de partida de la anhelada reconstrucción, "la piedra basal de nuestra actitud exterior". ${ }^{94}$ La grande Argentina de mito aglutinador se convertía en realidad tangible.

La reivindicación de las Malvinas constituía, desde siempre, uno de los temas preferidos del nacionalismo, por lo que el accionar de los militares generó una reacción eufórica. El regreso a las bases fundacionales estaba en los orígenes del movimiento. "Hoy la Argentina se muestra a sí mis-

90 Cabildo, N. ${ }^{\circ}$ 39, Buenos Aires, 1981.

91 "Editorial", Cabildo, N. ${ }^{\circ} 39$, Buenos Aires, 1981.

92 "La retaguardia en la guerra", Cabildo, N. ${ }^{\circ}$ 53, Buenos Aires, 1982.

93 Curutchet, Ricardo: "Un gesto para siempre", Cabildo, N. ${ }^{\circ}$ 52, Buenos Aires, 1982.

94 Ibídem. 
ma y ante el mundo digna de sus orígenes, de sus empresas heroicas y de su irrenunciable proyección histórica". ${ }^{95}$

La ocupación fue considerada un hecho irreversible y, por lo tanto, toda negociación debía ser encarada desde este punto de vista. La soberanía (imposible de ser negociada o puesta en discusión) estaba en juego; "Soberanía o Muerte" era la consigna que se expresaba en una portada. ${ }^{96}$

Por otra parte, el éxito inicial obtenido por las Fuerzas Armadas fue saludado como la emergencia de una nueva situación que revertía las claudicaciones del pasado inmediato; "se puede decir, a la vista de este clima triunfante en que se mueve el gobierno y de las inmensas expectativas que ha abierto, que ha refundado el Proceso al otorgarle una nueva legitimidad, al proponerle nuevos objetivos, al disponer de nuevas perspectivas. Es como si se hubiera penetrado en el túnel del tiempo hasta regresar a seis años atrás". ${ }^{77}$

Sin embargo, ante la convocatoria oficial a los partidos políticos se advierte que aquél "iSe vuelve a equivocar! Llama a sus enemigos, incluso los más declarados y se complace en rodearse de una clase partidocrática que viene fracasando desde hace generaciones y que acompañó, provocó, alentó o aplaudió el fracaso del Proceso". ${ }^{98}$ Pese a todo, dado el apoyo inicial de la sociedad a la ocupación, el momento lo evaluaron como una "posibilidad regeneradora" que debía aprovecharse.

Durante la guerra, la postura de Galtieri de no negociar y considerar imposible cualquier acuerdo que implicara el retiro de las tropas argentinas de las islas recibió un apoyo ferviente. Esto se desprende de lo que un acuerdo implicaría en la óptica nacionalista; el sometimiento a los dictados de Gran Bretaña y de los Estados Unidos, subordinando la nación a los caprichos de las potencias democráticas y liberales. Aludiendo a las vinculaciones de Gran Bretaña con el "tío Sam" y las Naciones Unidas, Cabildo plantea que "las alternativas de las negociaciones diplomáticas...resultan inmorales en absoluto". 99

Lo nacional se reivindicaba así en oposición a los intereses extranjeros, por lo que ceder implicaba una traición a la patria. El que los ingleses "nunca creyeron en una decisión política argentina de tamaña magnitud"100

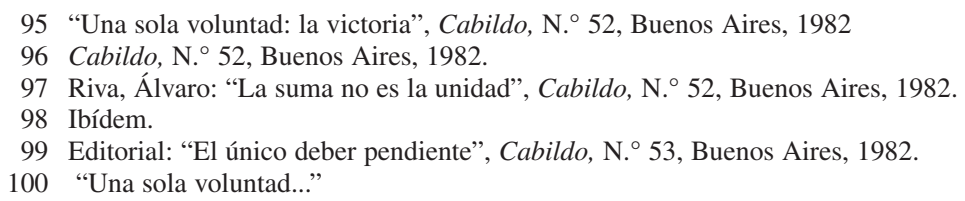


fue la premisa que sirvió para dar esperanzas a todos los que creyeron en la proximidad del triunfo. Se afirmó así el gran giro que daría la Argentina, tomando al mundo por sorpresa.

Si bien el hecho de haber declarado la guerra fue en sí mismo un acto glorioso, el reclamo continuo por la victoria en el campo militar como deber nacional muestra indicios de lo que la derrota representaría para la revista. Como medio específico la guerra era el terreno en el que se esperaba el mejor desempeño por parte de las Fuerzas Armadas : "las fuerzas armadas pueden errar en política, disparatar en economía, desbarrar en diplomacia, pero no faltar a la más mínima de sus obligaciones en defensa de la soberanía". ${ }^{101} \mathrm{Si}$, como estamos viendo, el tono de las críticas había cuestionado con fuerza la capacidad de la Junta Militar para gobernar, en última instancia podía llegar a atribuirse esta falencia al origen militar, ajeno a la arena política; pero en el campo militar se esperaba un triunfo. "La soberanía ya es nuestra: ahora nuestro deber es la victoria". ${ }^{102}$ La guerra fue así considerada como la instancia culminante del sentimiento nacionalista de recuperación de lo usurpado: "seremos dignos de nuestra mejor tradición". ${ }^{103}$ Este acto de grandeza rompía con las concesiones de la política exterior del Proceso y permitía por lo tanto una reformulación de las apreciaciones: "hasta ese entonces el país se debatía en un círculo vicioso y letal de dictadura vergonzante, extinción económica, desborde partidocrático, penuria social y astenia colectiva". ${ }^{104}$

El sentimiento, capturado por la revista, se correspondía directamente con hechos arraigados en el ideario nacionalista, tales como la Guerra de Independencia. Se estimaba que se había recuperado el sentir propio de aquellos años memorables: "la Argentina de hoy se ha sentido de pronto la Argentina de siempre y ha renacido en ella el vigor y el contento de los tiempos ilustres" ${ }^{105}$ Sumergidos en el discurso beligerante, eran continuas las referencias no sólo a la independencia sino también a las invasiones inglesas. El enemigo volvía a ser el mismo, la historia se repetía y por lo tanto el pueblo nuevamente debía repeler al invasor: la Argentina llamaba otra vez a "hervir el aceite y el agua". ${ }^{106}$ El intento de cruzada contra la descristianización del mundo se manifestaba en la guerra contra la Inglaterra

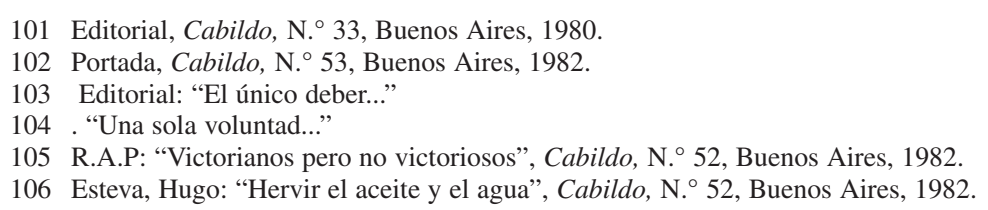


protestante, erigiéndose la Argentina en baluarte de los valores hispanos y de la tradición católica.

Es interesante destacar cómo la guerra en tanto recurso retórico poseía un carácter salvador, ya no sólo como medio para recuperar las Malvinas y con ellas la dignidad, sino también como legitimadora del proyecto nacionalista de Revolución Nacional y de construcción de la Nación Católica. Es por ello la última oportunidad para caminar por el sendero correcto, ya que "no hay como la guerra para crear opciones terminantes...ni mejor oportunidad para crecer y madurar". ${ }^{107}$

La guerra no se ve entonces únicamente como deber moral sino también como giro histórico para lograr purificar la nación: "sólo esperamos que fructifique y dure, que supere lo sensible y epidémico, que sea el germen de un nuevo amanecer y que nadie cometa el imperdonable crimen de truncar o desaprovechar esta posibilidad generadora". ${ }^{108}$

Es como si la guerra borrara el juicio que previamente se había hecho del accionar de la Junta Militar: "la situación interna se ha revertido 180 grados y hoy el proceso dispone de un enorme espacio político impensable días atrás". ${ }^{109}$ Esta modificación en las apreciaciones respondió a la creencia de que por fin sus demandas nacionalistas estaban siendo atendidas y la construcción de la Nación Católica empezaba a tornarse realidad.

Dado el apoyo inicial de la sociedad a la ocupación (el pueblo se concentró en Plaza de Mayo para celebrar la ocupación de las islas) el momento fue considerado como una posibilidad regeneradora, ya que "si las fuerzas armadas necesitaban un auténtico plebiscito sobre la acción cumplida, allí lo tuvieron". ${ }^{110}$ Así Cabildo definió aquel momento como el de la expresión auténtica de la nacionalidad. El gobierno se convertía así en el paladín de una vieja y legítima reivindicación; la manifestación fue apreciada como un apoyo explícito a la recuperación de las islas del Atlántico Sur, teniendo lugar una metamorfosis instantánea en el humor de la población que había agotado su tolerancia hacia la dictadura militar. El apoyo despertado respondía a ciertos cánones nacionalistas arraigados en la población argentina.

La derrota del 14 de junio fue sin duda un golpe tremendo. Replanteó el papel del Proceso de Reorganización Nacional y puso de manifiesto, des-

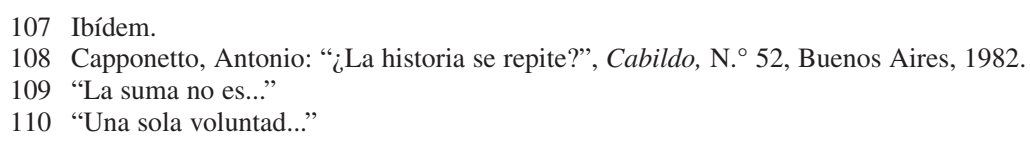


de la óptica de la revista, la separación existente entre la cúpula militar, y el resto de las Fuerzas Armadas. La expresión "traición" fue utilizada recurrentemente, acompañada de un sentimiento de decepción y necesidad de castigo al referirse a quienes, incumpliendo su deber para con la Patria, habrían dejado perder la batalla. La guerra fue por lo tanto el momento de mayor apoyo y la instancia de distanciamiento final. A partir de la derrota en el frente militar, las apreciaciones hacia el accionar de la Junta Militar no repararán en defensa alguna, salvo la del soldado, "baluarte de la nación".

Malvinas permaneció en el ideario de Cabildo como un momento sublime e imborrable, ya que a pesar de los sucesos posteriores, “...no fue un error ir a la guerra"; 111 no podía serlo si se tiene en cuenta la caracterización que se hacía de ella . El enfrentamiento fue la respuesta más acertada ante tantas humillaciones sufridas por parte de otras naciones ante las cuales la Argentina se había mostrado impávida e inmutable. Las ansias guerreras, que no se habían concretado con Brasil y Chile, por fin se efectivizaban, despertando la Argentina del aparente letargo en el que se encontraba, "la guerra no fue un paso en falso porque no puede serlo el ejercicio de la voluntad activa de todo un pueblo respecto de una reivindicación justa". ${ }^{112}$

A partir de la finalización del conflicto, la revista será crítica en cuanto al desarrollo de la guerra en sí y al apoyo otorgado a ella , como también en lo referente a la asignación de responsabilidades.

Se planteó que la Argentina "nunca estuvo en guerra, en verdadera guerra", ${ }^{113}$ a partir de las interpretaciones sobre el apoyo a la guerra por parte del frente interno, al cual se le otorgó un carácter importante, ya que en caso contrario, "de nada valen los soldados que combaten en primera fila". ${ }^{114} \mathrm{El}$ frente interno, compuesto por la sociedad, los altos mandos militares que impartieron órdenes desde Buenos Aires, y los partidos políticos, debió manifestar su compromiso con la recuperación de las islas. Aunque en un principio la exaltación popular en Plaza de Mayo confirmaría lo dicho, esta posición no se mantuvo durante la guerra, por lo que la falta de convicción que existió en el gobierno y también en parte de la sociedad condicionó, para Cabildo, el devenir militar. El escaso apoyo y, principalmente, las críticas de los partidos políticos motivaron en la revista una categórica

111 Editorial: "Las dos rendiciones de Buenos Aires", Cabildo, N. ${ }^{\circ}$ 54, Buenos Aires, 1982.

112 "De la borrasca bélica a la partidocrática", Cabildo, N. ${ }^{\circ}$ 54, Buenos Aires, 1982.

113 P.H.R.: "La guerra — si la hubo cabalmente— se perdió en Buenos Aires", Cabildo, N. ${ }^{\circ} 54$, Buenos Aires, 1982.

114 Esteva: "Hervir el Aceite..." 
definición del verdadero enemigo: "no hay peor enemigo que el interno". ${ }^{115}$ Todas estas ideas giraban alrededor de la idea de las dos Argentinas.

Su convicción respecto de la existencia de dos Argentinas, "una combatiente, otra especuladora; una con sentido metafísico y religioso de la guerra, otra materialista y frívola", ${ }^{116}$ los llevó a sostener que "la guerra no la ganó Gran Bretaña, sino aquella porción de la Argentina que nunca quiso la guerra y trató voluntaria o involuntariamente de perderla". ${ }^{117}$

Esta distinción analítica explica el desdoblamiento que desde Cabildo se hizo de las fuerzas militares: por un lado, la Argentina gobernante, cuyos errores precipitaron la pérdida de Malvinas, recayendo sobre ellos la responsabilidad por la derrota, y por el otro, el soldado combatiente. "Esta guerra nos enseña que en realidad nunca se pensó en que se iba a la guerra" ${ }^{118} \mathrm{Al}$ menos eso se consideró con respecto a los altos mandos, cuyo accionar no se correspondió con tamaña iniciativa, porque "hubo errores gruesos en la atención de los preparativos militares y diplomáticos, en la confección de las estrategias políticas; no se preparó a la opinión interna del país ni se puso a éste en pie de guerra". ${ }^{119}$

La consternación provenía de la ligereza con la que a su entender la ocupación había sido tomada. "¿Con qué derecho los generales, almirantes, brigadieres, entraron en una guerra y se retiraron de ella sin dar explicaciones?". ${ }^{120}$ La inmediatez de los acontecimientos llevó al apoyo ilimitado por parte de Cabildo al declararse la ocupación, pero el también sorpresivo retiro llevó a su definitivo distanciamiento.

La falta de atribución de responsabilidades con respecto a la retirada y la derrota marcaron la clara ruptura que tuvo lugar en el interior de las Fuerzas Armadas, ya que teniendo en cuenta que "hubo quienes no hicieron la guerra con entereza", ${ }^{121}$ el pedido de castigo fue una de las patas de la reconstrucción. El pasaje por la guerra fue fugaz, pero permanecerá en la memoria del colectivo nacionalista.

La reconstrucción nacional, asentada en la derrota, se erigió como demanda impostergable. Para su consecución se necesitaba de la recompo-

115 P.H.R: . "La Guerra..."

116 Ibídem.

117 Editorial: "Corrupción y Justicia”, Cabildo, N. ${ }^{\circ}$ 57, Buenos Aires, 1982.

118 "Dos guerras perdidas y una retirada sin honor. Tucícides", Cabildo, N. ${ }^{\circ}$ 67, Buenos Aires, 1983.

119 Riva, Álvaro: "Sombras en el 'Informe Malvinas", Cabildo, N. ${ }^{\circ} 71$, Buenos Aires, 1983.

120 "Los hombres pasan, el régimen queda", Cabildo, N. ${ }^{\circ}$ 55, Buenos Aires, 1982.

121 Esteva: "Hervir el Aceite..." 
sición de las Fuerzas Armadas y la asignación de responsabilidades; "exigimos incansablemente el supremo castigo a los traidores". ${ }^{122}$ El castigo es tomado como posibilidad regeneradora, como componente purificador de aquellos sectores enfermos y corrompidos que "hacen del uniforme un disfraz, del generalato una buena ocasión", ${ }^{223}$ y deben ser separados del cuerpo sano que constituían las Fuerzas Armadas vistas en su totalidad.

En todas las argumentaciones se percibe cómo, a pesar de las críticas proferidas al estamento militar, desde Cabildo se establece una clara distinción entre los oficiales de medio y bajo rango y aquéllos de mayor jerarquía. El soldado debe exigir respuestas "a los altos jefes que temblaron ante el deber y sobre todo al régimen que los entregó y que hizo inútil en lo inmediato su cruento sacrificio". ${ }^{124}$

La revista, en respuesta a las críticas realizadas por los partidos políticos a la gestión militar, hizo hincapié en la defensa ferviente del soldado. La publicación, sin duda, se hacía eco del pensamiento de ciertos sectores de las Fuerzas Armadas, "indignados por la manera en que las investigaciones gubernamentales han dejado a algunos generales culpables sin tocar", ${ }^{125}$ pero también enardecidos porque "los políticos aprovechan para denostar a las FFAA globalmente", ${ }^{126}$ es decir, sin discriminación alguna entre los soldados y la conducción.

Esta distinción tan fuerte entre las Fuerzas Armadas como institución y la cúpula militar en el gobierno respondió a la necesidad de reconocer la pureza del estamento militar y de su función imprescindible en la sociedad. Las fuerzas militares son "una aristocracia con clara conciencia histórica y con claro sentido de su deber político y cultural. Pero las FFAA argentinas han olvidado su función, han olvidado sus obligaciones y han repudiado su destino...sólo su esencia las preserva de su existencia". ${ }^{127}$ No obstante, afirmaban que "a pesar de sus vicios y de sus errores, esconden en su naturaleza la posibilidad postrera". ${ }^{128}$

Se reclama la remoción de los responsables antes de que los partidos políticos tomen esa bandera en su nombre, ya que siendo "instrumentos del poder extranjero, se hallan dedicados a la tarea de recortar el poder militar

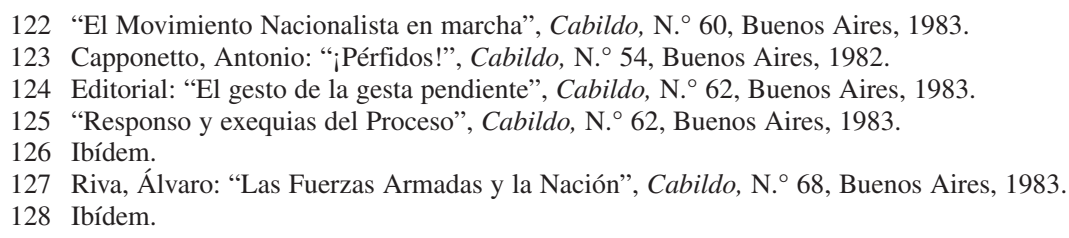


argentino". ${ }^{29} \mathrm{Y}$ esto no podía ni debía ser permitido, por entender a las Fuerzas Armadas como la institución fundamental para la estabilidad y el orden. "Las fuerzas deben limpiarse, liberarse de la cúpula oligárquica que las ha deformado", ${ }^{130}$ pero esta tarea les compete solamente a ellas.

La culpabilidad, por supuesto, no sólo recaía en la cúpula militar sino también en el accionar de los partidos, ya que "no habrá victoria mientras no se declare la guerra a quienes trocaron la guerra justa por el circo partidocrático". ${ }^{131}$ El frente interno, identificado también con los partidos políticos que no quisieron ni apoyaron la guerra, es responsabilizado por la derrota. La apertura democrática será, como veremos seguidamente, cuestionada con dureza a fin de concienciar respecto del peligro de consagrar a un partido en el poder. Las dos derrotas, consideradas así por Cabildo, fueron achacables al alto mando castrense, "una la del 14 de junio frente a los soldados británicos; y la otra frente a la partidocracia local". ${ }^{132}$

La recomposición de las Fuerzas Armadas, en tanto sostén de la nación, se tornó inminente, teniendo en cuenta que la Nación no podría florecer con sus bases corrompidas. La importancia otorgada al estamento militar radicaba en considerar al ejército la institución pre-liberal más importante, basada en el orden, la jerarquía, el corporativismo y era, para los nacionalistas, la encargada de restaurar la moral a la patria, entendida en este caso como una restauración acompañada de la limpieza de sus filas. La oligarquía castrense debía ser desterrada, pero "no en nombre de la democracia sino de las fuerzas armadas, no en nombre de la plebe izquierdista sino de los oficiales jóvenes que no saben servir a la Patria sino a través de estas instituciones que son anteriores a todas las demás". ${ }^{133}$ La iniciativa debía venir de la mano de los militares evitando intromisiones arbitrarias.

\section{f) El retorno a la democracia}

La guerra evidenció de manera concreta todas las falencias del Proceso de Reorganización Nacional que desde Cabildo se venían enume-

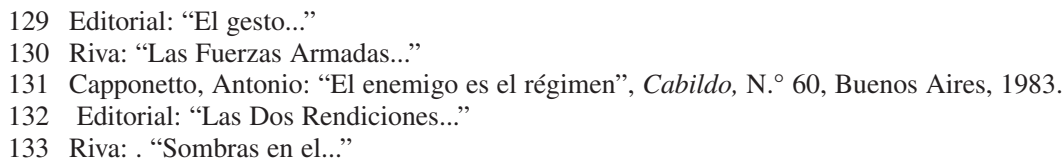


rando, y las potenció. Quedó así al desnudo, para los nacionalistas católicos, la república liberal en todas sus facetas: "la derrota de Puerto Argentino y en general, el Estado de postración, de fracaso y de humillación que vive y soporta la Nación, pertenece... a la historia de la república Liberal: la Argentina está como está porque es liberal". ${ }^{34}$ Ante la realidad concreta de la derrota militar se volvió al clima de críticas previo a la guerra, pero esta vez más enardecido. La radicalización respondía al desenmascaramiento del gran enemigo: el liberalismo.

El proceso fue evaluado como "la culminación del régimen liberal implantado en, sobre y contra el país desde 1852 ". ${ }^{135}$ Si bien lo ocurrido recaía, como se ha visto, sobre el actual gobierno y las Fuerzas Armadas, el carácter liberal que tiñó el desarrollo de la Nación desde Caseros fue considerado el verdadero responsable. Se incriminó así al liberalismo y a la generación del ' 80 , responsable porque "nos hizo prósperos y modernos, pero por supuesto al modo iluminista: en forma cruel, a un precio altísimo, bajo un signo ideológico y contra la realidad... Si bien había transformado a la Nación, también la había trastocado; así como la había hecho progresar, también la había puesto en cuestión hasta llevarla a una confusión exasperada que en estos días alcanza los picos de caos"136; por supuesto, contradictoria con los valores nacionales y católicos.

Otra de las lecturas de la revista analizaba la internacionalización en clave del sometimiento de las naciones a los dictados del exterior y como pérdida de su derecho soberano. "La pérdida de Malvinas era no sólo una fracturación territorial sino la expresión corpórea de aquel sometimiento". ${ }^{137}$ En esta línea, el liberalismo era la ideología que por excelencia se había encargado de conducir los asuntos nacionales, sometiendo al país.

La introducción del componente liberal en la argumentación de Cabildo es sumamente interesante, no (por supuesto) por lo novedosa, sino por su funcionalidad en este caso en particular. Si bien la cúpula militar es fuertemente criticada y cuestionada, la crítica no se centra en la esencia de dicha institución, sino en la debilidad de algunos militares que encarnan el espíritu castrense. Éstos flaquearon frente al liberalismo y respondieron a intereses contrarios al sentir y a la especificidad militar. El liberalismo

134 Curutchet, Ricardo: "Las dos traiciones del Proceso", Cabildo, N. ${ }^{\circ}$ 58, Buenos Aires, 1982.

135 Ibídem.

136 Editorial: "La cría del 'Proceso"”, Cabildo, N. ${ }^{\circ}$ 68, Buenos Aires, 1983.

137 Riva, Álvaro: "Que la derrota militar no se convierta en política", Cabildo, N. ${ }^{\circ} 68$, Buenos Aires, 1983. 
corrompió a la cúpula militar; se afirma así que "el sistema liberal, se levantó hasta ahora sobre dos pilares a los que recurrió según sus necesidades: los partidos políticos y las fuerzas armadas". ${ }^{138}$ Esta distinción es necesaria para el nacionalismo católico a los efectos de intentar comprender por qué las Fuerzas Armadas, en las que habían depositado tantas esperanzas, no respondieron a sus expectativas.

Era importante para Cabildo establecer una clara distinción entre la guerra y la batalla. Si se consideraba a la guerra aún no perdida, entendiendo que era librada contra el liberalismo, y sólo daba por perdida la batalla de Malvinas, podría esperarse el apoyo nacionalista y evitar la intromisión de los partidos. El llamado a elecciones era la pérdida de la guerra. "Hay que evitar que la derrota militar se convierta en derrota política, ya que lo que se perdió fue la batalla, no la guerra".

La pendiente que condujo a los militares hacia la entrega del poder a los partidos políticos exacerbó en el discurso de Cabildo tanto el cuestionamiento a la jerarquía militar protagonista del Proceso de Reorganización Nacional, como la descalificación anticipada del régimen que se instaló tras las elecciones del 30 de octubre de 1983.

Ante la apertura democrática, Cabildo dedicó todos sus esfuerzos en destacar el error que se iba a cometer, aduciendo que al ser los partidos políticos el arma política del liberalismo, no debía permitirse su convocatoria ya que nuevamente se implantaría de su mano un orden contrario a la nación. Resultaba inimaginable concebir que "los caídos habían ido a la muerte para reponer en el Estado al peronismo o a la UCR". ${ }^{139}$ La incoherencia de restablecer a los partidos políticos anulaba la pretensión militar de intervención para salvaguardar el orden, ya que ¿qué tipo de orden podía instaurarse de la mano de los partidos políticos, considerados responsables del temible caos contra el cual se había erigido Cabildo? Esta contradicción, para quienes hacían la revista, era contundente. Su apoyo sólo era justificado mientras el Proceso respondiera aunque fuera de manera parcial a sus demandas, pero de ningún modo podía ser apoyado el restablecimiento de la culpable partidocracia. El distanciamiento definitivo se había consumado.

138 Editorial, Cabildo, N. ${ }^{\circ}$ 55, Buenos Aires, 1983.

139 "El suspiro civil crece en quejido", Cabildo, N. ${ }^{\circ}$ 55, Buenos Aires, 1982. 


\section{Conclusiones}

"Demasiado antiguo todo". ${ }^{140}$ Así valora el más destacado estudioso actual de la derecha tradicionalista española las postulaciones de los grupos nacionalistas católicos en los años previos a la guerra civil de 19361939. ¿Qué cabe entonces decir de quienes, cuarenta o cincuenta años más tarde, defendían casi sin variantes las mismas ideas?

Las contradicciones entre el gobierno del Proceso y el ideario de los editores de Cabildo emergieron como lógica consecuencia de las enormes diferencias existentes entre la realidad concreta y los deseos de los nacionalistas. Los militares del Proceso tenían un proyecto, pero éste sólo circunstancialmente podía coincidir con quienes aspiraban a construir un "orden nuevo", cuyas raíces se encontraban en la sociedad medieval.

Los defensores a ultranza del realismo político, que descalificaban la Revolución Francesa por "utópica" y "apriorística", no percibían (o no querían percibir) la distancia que separaba a la compleja sociedad argentina de su proyecto, antidemocrático y aristocratizante. Si bien es cierto que la soberanía popular no entraba en lo más mínimo dentro de su discurso, su visión del futuro debía tener algún anclaje real, actores sociales de peso que la compartieran. La inviabilidad de su propuesta, que arrasaba tanto con el liberalismo como con la democracia de partidos, aseguraba su aislamiento, más allá del apoyo individual de algunos miembros de las clases dominantes.

Podían producirse momentos en los cuales los militares en el poder parecían responder a sus expectativas - y el tratamiento dado a algunas de las figuras de esos años, como el general Ramón Camps o el almirante Emilio Massera parecía mostrarlo-, pero la tajante dicotomía que establecían entre quienes estaban del lado de la patria y sus enemigos, del caos en contraposición a la Nación, de las dos Argentinas, no contribuía en manera alguna a establecer fórmulas de acercamiento duradero. El hecho de sentirse poseedores de la verdad llevaba inevitablemente a la intolerancia, a la descalificación del "otro", que no merecía consideraciones ni miramientos. Los integrantes del Proceso no escapaban a ese tratamiento; podían ser elogiados de manera coyuntural, sobre todo en tanto integrantes del poder militar, al que reconocían como tronco constitutivo de la patria, pero si no

140 González Cuevas: Acción Española..., pág. 399. 
asumían "in toto" su programa de construcción de la nación católica, el desencuentro era inevitable.

Por lo tanto, no es casual que, salvo situaciones excepcionales, los militares no contaran con ellos. Eran aliados útiles para algunos menesteres - el tema de su incidencia en la política cultural del Proceso merece ser estudiado- pero en general terminaban resultando incómodos. Constituye sin duda un hecho relevante que un número de la revista llegara a prohibirse, y que discursos de los Comandantes en Jefe tuvieran párrafos implícitamente dirigidos a condenar su intransigencia.

Es que la propuesta nacionalista, capaz de encontrar seguidores entre algunos miembros de las Fuerzas Armadas, carecía, como se ha dicho, de toda viabilidad para ir más allá de santificar la "guerra sucia" y descalificar la democracia. Con todas sus contradicciones a cuestas, la mayoría de los militares del Proceso de Reorganización Nacional no estaban dispuestos a llegar tan lejos como para impulsar un proyecto tan excluyente, en el que no había lugar más que para "cruzados" imbuidos de la convicción de estar en posesión de la verdad absoluta. 